\title{
Erratum to: Effect of Process Parameters on the Structure and Properties of Galvanized Sheets
}

S.K. Shukla, B.B. Saha, B.D. Tripathi, and Ram Avtar

\section{Erratum to: J. of Materi Eng and Perform \\ DOI 10.1007/s11665-009-9527-2}

Please note that the correct spelling of the third coauthor's surname is "Tripathi".

The online version of the original article can be found under doi:10.1007/s11665-009-9527-2.

S.K. Shukla, B.B. Saha, B.D. Tripathi, and Ram Avtar, Materials Technology Group, R \& D Centre for Iron \& Steel, Steel Authority of India Ltd., Ranchi, India. Contact e-mail: shklsnjv@yahoo.co.in. 